\title{
APPRECIATION OF RUPIAH: BENEF ITS, COSTS, OPPORTUNITIES, AND RISKS (BCOR) ANALYSIS
}

\author{
Piter Abdullah* \\ Centre for Education and Central Banking Studies \\ Bank Indonesia \\ Jakarta \\ Indonesia \\ E-mail: Piter@bi.go.id
}

\begin{abstract}
This paper studies the controversial implications of rupiah appreciation from all possible angles. We use the benefits, costs, opportunities and risks (BCOR) analysis to understand the mixed effects of rupiah appreciation and to determine the most appropriate policy response that generate the highest benefit to the Indonesian economy. We capture the stances and views of government officer, central banker, and businessmen going for and against rupiah appreciation in the long-term and short-term perspectives. Considering the uniqueness of Indonesian economic structure, the underlying hypothesis is that Indonesia stands to achieve the highest advantage from Rupiah appreciation.
\end{abstract}

Keywords: Currency Appreciation, BCOR Analysis, Analytical Network Process.

\section{Introduction}

The Indonesian currency, rupiah, has undergone a rapid and significant appreciation in the last two years. Averaged over the last two years, the rupiah strengthened $26 \%$ from Rp12,151 per US dollar in November 2008 to Rp9,013 per US dollar in November 2010. The appreciation of rupiah was supported not only by solid fundamentals reflected in the significant current account surplus, but also by global liquidity glut, strong expectations of continued low interest rates in developed nations and the induction of Quantitative Easing II by the Fed.

The rapidly appreciating rupiah, however, triggered a controversy. On the one hand, it is believed to be potentially harmful to the Indonesian economy. Some analysts have warned that 'much stronger' rupiah may signal danger for Indonesia's exports. In addition, other analysts are more worried that the risk of sudden capital reversal can shock the entire Indonesian economy. On the other hand, it is also believed that a strong rupiah has its advantages. The strong rupiah, as a result of appreciating rupiah, not only will increase purchasing power of the Indonesian people but also ease the burden of government and enterprises with foreign currency debts. In the mean time, to curb the exposures, Bank Indonesia (BI) have continuesly intervened the market to slow down the rate of rupiah appreciation and imposed "soft capital control" measures by lengthening the maturity profile of term deposits as well as the minimum holding period for BI certificates (SBIs).

On top of that controversy, the main questions should be: 1) what are actually the ultimate impacts of appreciating rupiah on the whole Indonesian economy, and 2) what is the best policy response should be taken by the Indonesian government (GOI) and the central bank (BI) with regard to the current

\footnotetext{
${ }^{*}$ The author is senior economist at Centre for Education and Central Banking Studies, Bank Indonesia. The views expressed in this paper are those of the author and do not necessarily reflect those of the Bank Indonesia.
} 
appreciating rupiah. This paper attempts to answer those questions by taking into account all possible impacts of appreciating rupiah from all possible angles. We use the benefits, costs, opportunities and risks (BCOR) analysis in determining the most appropriate policy response that generate the highest net benefit to the Indonesian economy. To synthesize all dimensions of BCOR we apply Analytic Network Process (ANP).

\section{Literature Review}

\subsection{Factors Causing Currency Appreciation}

What factors causing a currency like rupiah to appreciate or depreciate? Actually there are so many factors affecting a currency flotation against foreign currency such as US dollar. In general, it is depend on supply and demand of that fore ign currency. Normally, the demand of a foreign currency is indicated by the amount of foreign expenses for import, debt payment, etc. On the other hand the supply of foreign currency comes mostly from export and capital inflows. While export and import are fully determined by the structure and economic condition, capital inflows for some cases are driven by speculative motives. The appreciation of a currency initiated by the improvement of the structure and economic condition may be long lasting. On the other hand, the appreciation of currency as a result of speculation inflows may be just a shortime shock.

Balassa Samuelson Hypothesis (BSH) is one of some literatures trying to answer what factors determining the level of real exchange rate in long run. It provided a framework of relationship between the real exchange rate (currency flotation) and the productivity (the structure and economic condition). According to $\mathrm{BSH}$, economy with faster productivity growth in the tradable sector would experience a real appreciation of its currency. Assuming that purchasing power parity (PPP) holds for tradable goods, $\mathrm{BSH}$ argues that productivity growth is slower in the non-traded service sector than in the tradable goods sector. As wages rise with productivity in the goods sector, it leads to an upward trend in the relative price of services. To the extent that the general price level is a weighted average of tradables and non-tradables, an economy with faster productivity growth in the tradable sector would experience a real appreciation.

\subsection{The Impact of Currency Appre ciation}

In short-term the currency appreciation may hit the export-oriented manucfacturing sector since it will increase the relative price of those manufacturing goods on the global market. It is worthy to note, however, that it may not be the case as the exporters can maintain their competitiveness by lowering the international price of their manufacturing goods on the global market. The exporters can choose not to realize all of the potential prof its that they can gain from the currency appreciation. It may also not be the case when the export are dominated by raw material goods whose demand are relatively inelastic to the price.

On the other hand, the currency appreciation shortly will make foreign product less expensive and people will be more confident and willing to spend on imported goods. The lower price of imported goods will also make it possible for government to execute giant infrastructure projects that need much imported goods. Accordingly, when currency appreciating the sale of imports rise in relation to exports.

A major advantage of currency appreciation in shortterm is that it will instantly decrease the burden of servicing and repaying of foreign debt of government and those companies that has raised foreign currencies denominated debt. This advantage will be amplified in the case of short term debt as the burden is immediately felt. In the case government has to subsidize imported good like oil, currency appreciation will also instantly decrease that burden, and government can shift the fund for other priority sector. 
Since currency appreciation will reduce the cost of imports, consequently in the long-run it will decrease what is called imported inflation lead to general economy-wide prices decreasing. This lower inflation could discourage the central bank from raising interest rates and will induce investment and therefore economic growth. Lower interest rate could be an advantage both for central bank and government since it may decrease monetary and fiscal policy burden (decreasing expenses for government bond coupon).

On the other hand lower interest rate will also discourage capital inflows. In the case of short-term capital inflows or hot money, this impact will be an advantage. In the case of foreign direct investment (FDI), however, this impact will be a disadvantage since it will lower economic growth. Shrinking capital inflows will adjust the currency exchange rate.

As the currency appreciation make lots of people in the long-run feel relatively richer $^{1}$ with enhanced net worth, at least in accounting terms, it will increase their investments to local assets, especially real estate properties $(\mathrm{Xu}, 2008)$. Together with decreasing interest rates - as a result of lower inflation - this increasing domestic demand will boost demand for credit. As a final result, investment will be higher and make more space for economy to grow.

There are two theories explaining how the level of income or economic growth is connected to the level of the exchange rate. The first is Balassa-Samuelson hypothesis (BSH) and the other is productivity differential theory. BSH explains that an economy with faster productivity growth in the tradable sector would experience a real appreciation. The causation between the real exchange rate and productivity growth, is presumed to run from the latter to the former. This argument is supported by facts that fast growing economies may have a tendency to experience some appreciation of their curencies.

Productivity differential theory, however, argues that there is intricate mutual interaction between the real exchange rate and productivity differentials. Sometimes, the causation runs from the former to the latter.

$\mathrm{Xu}$ (2008) analyzed the long-run effects of Taiwan dollar appreciation. According to Xu (2008), the appreciation of the Taiwan dollar could be regarded, to a large extent, as being exogenous with regard to goods markets, because it was driven mainly by speculative capital flows in financial markets. In the short run, it caused enormous pains in terms of declines in production and employment in traditional export industries, and it did not contribute unambiguously to better monetary policy. However, it did bring about the sizeable long-run benefits in pushing forward the upgrading process in manufacturing and the whole Taiwan economy.

\section{Appreciation of the Indonesian Rupiah: Searching The Best Policy Response}

\subsection{Review on Indonesian Economy}

Indonesia is the largest economy in Southeast Asia. After experiencing downturn in the second half of 2008, Indonesia's economy has begun to recover following the general elections in 2009. Indonesia was one of the best performing economies through the global economic crisis of 2008-2009. Although the economy slowed significantly during the cris is but it still grew by $6.01 \%$ in 2008 and $4.55 \%$ in 2009. It is expected to continue at about six percent through 2011 and increase to seven to eight percent in future years.

Indonesia's economy vastly relies on the agriculture, manufacturing and services sectors for growth. In 2009 , agriculture as the biggest employment sector -absorbing around $45 \%$ of workforce- contributes $13.6 \%$ to the country's GDP. Some of the major produce of Indonesia includes rice, tea, coffee, cocoa,

\footnotetext{
${ }^{1}$ It should be noted that currency appreciation in short-term may generate a negative wealth effect if residents hold large stocks of foreign assets. Appreciation would reduce the local currency value of foreign assets (Xu, 2008).
} 
spices, rubber, copra, peanuts, eggs, pork, poultry and palm oil. Indonesia is one of the largest producer of palm oil and coffee. The manufacturing sector absorbs around $18.8 \%$ of workforce and contributes $27.9 \%$ to the country's GDP. Another pillar of Indonesian economy, services sector, absorbs $37 \%$ of workforce and contributes $38.5 \%$ to GDP.

Indonesia had persistent balance-of-payments difficulties with deficits on oil trade balance, services and incomes. Surpluses from trade balance of gas and other goods (non oil and gas) did not provide sufficient exchange for debt repayments or for other invisibles, such as profit remittances on foreign investment and interest payments on government loans from abroad. With regard to export, Indonesia does not depend on manufacturing products, but more diversified. This is the reason why Indonesia could survive the global economic crisis in 2008-2009, while emerging countries like South Korea, Singapore, Taiwan, suffered and experienced economic contractions.

Since sources of growth of Indonesian economy is dominated by domestic demand, especially consumption, the main challenge ahead faced Indonesia is how to increase investment. In this context, however, Indonesia does have a substantial problem. Indonesia doesn't have adequate infrastructure. Aswicahyono and Friawan (2007) reported that the infrastucture condition in Indonesia has been in crisis in the last ten years. The road condition, for instance, are either severely congested or pooly maintained. Indonesia has only about $600 \mathrm{~km}$ of highway to cover total land area of 1,919,317 square kilometres for more than 230 million people. As a comparison, Malaysia has about 1,600 km of highway to cover total land area of 329,847 square kilometres (about one fifth of Indonesia) for 28.25 million people (about one eighth of Indonesia). According to Aswicahyono and Friawan (2007), at the same time Indonesia still lag far behind its neighbors with regard to teledensity, electricity, and water supply. This illustration indicates that Indonesia need to fasten its infrastucture development in order to improve investment climate, thus enhance competitiveness in the manufacturing sector.

\subsection{Setting the Network}

Using the logic of those short-run and long-run impacts of currency appreciation described above we can build a framework utilizing the analytical network process to figure out the best policy response with regard the appreciation of rupiah. The network can be illustrated in figure 1.

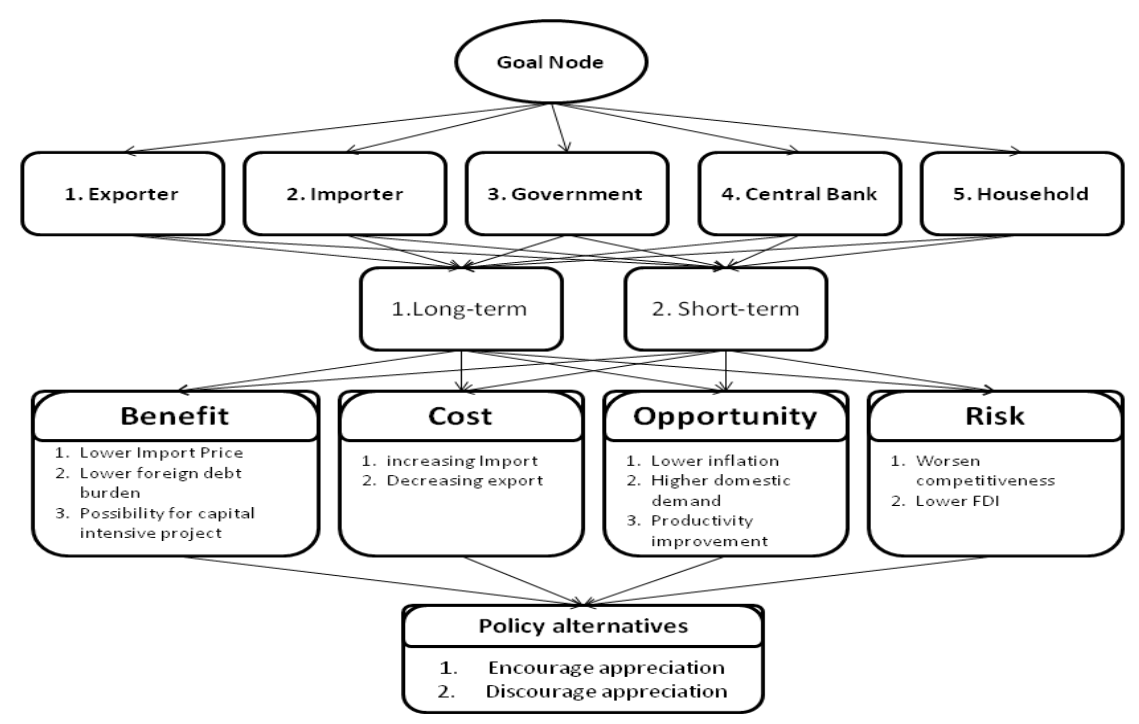

Figure 1. Benefits Costs Opportunities and Risks (BCOR) Analysis on Rupiah Appreciation 
As can be seen in figure 1, there are five players affected by the appreciation of rupiah. Those players are: exporter, importer, government, central bank, and household. Each player will be affected in short-run and in the long-run. The advantages or benefits that players can gain from rupiah appreciation would be the decreasing import price, lower foreign debt burden, and the possibility to execute giant infrastructure projects. The disadvantages or costs beared by the players would be the increasing import and decreasing export (both will hurt the balance of payment). The rupiah appreciation may also create opportunities for players to have lower inflation, higher domestic demand, and finally productivity improvement especially in the manufacturing industry. The only risk faced the players because of rupiah appreciation would be worsen competitiveness and lower foreign direct investment. It should be noted, however, that both opportunities and risks may not be realized if prerequisite events do not exist.

To find out the best policy response with regard the rupiah appreciation we synthesize all dimensions of BCOR in figure 1 above by using Analytic Network Process (ANP) based on hypothetical pair-wise comparison derived from data on Indonesian economy. We report three simulations. First, we simulate baseline scenario in which each players i.e. government (GOI), central bank (BI), exporter, importer and households has the same contribution to Indonesian economy, but have no time frame priority. Second, we simulate alternative scenario 1 in which each players has different contribution to Indonesian economy and have different time frame priority. We assume that government, central bank, and households has the same contribution to Indonesian economy but much bigger than export and import. Contribution of export and import, on the other hand, we assume are the same. Last, we simulate alternative scenario 2 in which each players has different contribution to Indonesian economy but have the same priority which is a longterm time frame.

\subsection{Result and Analysis}

The overall synthesized priorities for policy alternatives can be read in table 1 below.

Table 1 The Overall Synthesized Priorities

\begin{tabular}{|lccc|}
\hline Policy Alternatives & Baseline & Scenario 1 & Scenario 2 \\
\hline Encourage Rp Appreciation & 0.5055 & 0.5101 & 0.5269 \\
\hline Discourage Rp Appreciation & 0.4944 & 0.4898 & 0.4730 \\
\hline
\end{tabular}

It is shown in Table 1 that under the baseline scenario, in which all players assumed to have the same contribution to Indonesian economy, there is almost no different between to encourage rupiah appreciation and to discourage rupiah appreciation. This result shows a pure balance between pros and cons with regard rupiah appreciation, without taking into account the economic structure and time frame perspective.

The net benefit and opportunities are becoming larger in scenario 1 when we consider the economic structure of Indonesian economy; we take into account the different contribution of each players to Indonesian economy. The result implies that considering the economic structure of Indonesia in which export is not dominant, to encourage rupiah appreciation is a better policy response. To some extent there are net benefits and opportunities that can be gained through this policy response. Rupiah appreciation will lower the inflation, boost the domestic demand, make it possible for government to implement giant infrastucture project, and finally improve the whole Indonesian economy. All benefits and opportunities are greater than costs and risks.

In scenario 2, the result shows that if all players have the same perspective, i.e. long-run, it becomes obvious that to encourage rupiah appreciation is a much better policy response. In the long-run, some costs can be mitigated or even be avoided. 


\section{Closing Remarks}

The above analysis of the appreciation of rupiah has two important findings. First, the currency appreciation actually involves some players, some aspects, and some criterias. For that reason, the phenomenon of currency appreciation shouldn't be countered partially based on one negative impact from short-run perspective of one player. Such policy making process may generate sub-optimal policy response and cause the country lose a chance to improve productivity in manufacturing sector and to change the country's economic structure. Some developed countries like Germany, Japan, Australia, and Taiwan are good models showing that an appropriate policy response to curency appreciation can improve productivity in manufacturing sector and change the country's economic structure.

Second, the results of benefis, costs, opportunities and risk analysis show that to encourage rupiah appreciation is a better policy response even if all players have the same contribution to Indonesian economy. To encourage rupiah appreciation appears to be more dominant when we take into account the economic structure of Indonesia in which export is diversified, not depend on manufacturing products, and we assume that all players have the same time frame priority i.e. longrun.

Since sources of growth of Indonesian economy is dominated by domestic demand, especially consumption, and the main challenge ahead faced Indonesia is how to increase investment, Indonesia should consider the appreciation of rupiah in the long-run as a good opportunity. Accordingly, when rupiah is appreciating it would be better for Indonesian government and central bank to maintain the momentum instead of fighting back. GOI and BI might put the focus not on the trend of currency appreciation but the speed. Gradual appreciation in the rupiah will help all players to make adjustment in order to optimilize all benefits and opportunities, to reduce the costs, and to mitigate the risks.

\section{REFERENCES}

Aswicahyono, H., Friawan D. (2007). Infrastucture Development in Indonesia, In Nagesh Kumar (Ed.) International infrastructure development in East Asia - towards balance regional development and integration (131-165). ERIA Research Project Report 2007 No.2. Economic Research Institute for ASEAN and East Asia. Jakarta

Balassa, B. (1964). The Purchasing-Power-Parity Doctrine: A reappraisal. Journal of Political Economy, 72(6), 584-596.

George, K.K., Remya S. Impact of rupee appreciation on non-resident Malayalees. Working paper No.18. Centre for Socio-economic \& Environmental Studies (CSES).

Rodgers, Y. (1994). Estimation of devaluation impact on Indonesian Aggregate Trade Performance. Development Discussion Paper No.448. Harvard Institute for International Development-Harvard University.

Singh, Sumanjeet. (2009). Depreciation of the Indian currency: Implications for the Indian economy. AIUB Business and Economics Working Paper Series, No. AIUB-BUS-ECON-2009-04.

$\mathrm{Xu}$, Yingfeng. (2008). Lessons from Taiwan's experience of currency appreciation. China Economic Review, 19, 53-65. 